\title{
THE LABILE FACTOR OF PROTHROMBIN CONVERSION : ITS CONSUMPTION UNDER NORMAL AND PATHOLOGICAL CONDITIONS AFFECTING BLOOD COAGULATION 1, 2
}

\author{
By BENJAMIN ALEXANDER, ROBERT GOLDSTEIN, AND GRETA LANDWEHR \\ WITH THE TECHNICAL ASSISTANCE OF EUNICE ADDELSON \\ (From the Yamins Research Laboratory, Beth Israel Hospital, and the Department of Medicine, \\ Harvard Medical School, Boston)
}

(Submitted for publication September 28, 1950; accepted, December 11, 1950)

\section{INTRODUCTION}

The rapid conversion of prothrombin to thrombin by thromboplastin plus calcium requires a plasma component called "Labile Factor" $(2,3)$, which is probably identical with plasma Ac-globulin and Factor $\mathrm{V}(4,5)$, and with the prothrombin accelerator of Fantl and Nance $(6,7) .^{8}$ Deterioration of this substance as plasma ages produces an increase in the prothrombin time $(2,3,8)$ although the concentration of prothrombin remains essentially unchanged $(9,10)$. This defect can be rectified by the addition of fresh plasma devoid of prothrombin as well as of fibrinogen $(11,8)$.

Additional information regarding Labile Factor (L.F.) is desirable for several reasons. Its precise role in prothrombin conversion is obscure, and hemorrhage referable to deficiency of this entity or of a similar substance has been described (12-14). Furthermore, as will become evident, the concentration of L.F. must receive due consideration in procedures which measure prothrombin.

In certain hemorrhagic diseases the conversion of prothrombin to thrombin is reduced or retarded $(15,16)$. The "prothrombin consumption test," which demonstrates this defect, promises to become important in the investigation and diagnosis

\footnotetext{
1 Supported by a grant from The Commonwealth Fund.

2 Presented in part before the Federation of American Societies for Experimental Biology, April, 1950 (1).

${ }^{3}$ It should be pointed out that most investigators feel that Labile Factor, Factor V, plasma Ac-globulin, and the factor of Fantl and Nance are identical. Thus Quick and Stefanini (31) use the terms interchangeably to designate one entity. Seegers and his associates (10) are inclined to agree that Ac-globulin is the same as L.F. and Factor V $(30,40)$. We (24) as well as Flynn and his coworkers (41) hold the same view. Definite proof regarding the identity of all these moieties, however, is still lacking.
}

of such disturbances. In order to compute the consumption of prothrombin during coagulation, the precise amount of prothrombin in both serum and its parent plasma must be known. Obviously changes in the concentration of L.F. in the transition from plasma to serum may influence considerably the velocity of prothrombin conversion in serum and, therefore, the determination of serum prothrombin by the one-stage procedure, since the prothrombin times may reflect the concentration of L.F. as well as that of prothrombin itself. Under such circumstances the computation of prothrombin consumption from differences between plasma and serum prothrombic activities may be erroneous.

Whereas the concentration of L.F. has been determined in the plasma of man and other species (17), little is known regarding its level in serum. This information is presented in the present report. Also included is a method proposed for the determination of serum L.F. The data indicate that during and after coagulation changes in this clotting factor occur which are considerably influenced by conditions, pathological or induced, which affect clotting.

\section{METHODS}

Prothrombin determination: The prothrombic activity of oxalated plasma (one volume of $0.1 \mathrm{M}$ sodium oxalate to nine volumes of blood) was determined on undiluted plasma by the orthodox one-stage procedure (18), and on diluted plasma by the modification (19) in which the test plasma is diluted with fresh normal oxalated pooled plasma rendered prothrombin-free by adsorption with $\mathrm{BaSO}_{4} .4$ Prothrombin levels were calculated by interpolating the observed prothrombin times on standardization curves obtained on normal plasma similarly diluted. Serum prothrombin was measured similarly and also

\footnotetext{
4 Plasma so treated is hereafter referred to as " $\mathrm{BaSO} 4$ plasma."
} 
by the modified two-stage method of Ware and Seegers (20).

Labile factor: Pooled oxalated plasma from normal subjects was stored at $4-5^{\circ} \mathrm{C}$ for variable intervals during which its prothrombin time increased progressively. L.F. activities of test plasma or sera were measured by their restorative effects on the elevated prothrombin time of these aged plasmas in which the factor had largely deteriorated $(8,17)$. The restorative effect was determined by adding up to one part of plasma or serum (whole or diluted with physiological saline) to four parts of the aged plasma, and by observing the prothrombin times of the mixtures. The values herein reported are the averages of several observations on each mixture. In ranges below 45 seconds the prothrombin times were always duplicable within two seconds; between 45 and 60 seconds, within four seconds.

Except where otherwise indicated, the serum was separated one hour after venous blood was allowed to clot in a glass tube at room temperature. The clot was rimmed and centrifuged, and the serum was removed and incubated at $37^{\circ} \mathrm{C}$ for 15 minutes in order to inactivate thrombin. The time interval between incubation of the serum and determination of its activity was noted. Experiments were run on non-oxalated as well as oxalated serum ( 1 oxalate to 4 serum). In some instances citrate (2.5 per cent sodium citrate) was used instead of oxalate. Also studied were sera which were subjected to adsorption with $\mathrm{BaSO}_{4}$ for 10 minutes at $37^{\circ} \mathrm{C}$. Controls for the latter experiments were incubated for the same interval without $\mathrm{BaSO}_{4}$.
Commercial thromboplastin (Difco) and beef lung thromboplastin were used in the one- and two-stage methods, respectively.

\section{RESULTS}

The experiments reported below are typical of a series of experiments performed under the same conditions.

Comparative effect of normal serum and plasma on prothrombic activity of aged plasma

Oxalated fresh plasma has a profound restorative effect on the retarded prothrombin conversion of stored plasma (Figure 1). This is not due to the prothrombin in the fresh plasma, since removal of the prothrombin by $\mathrm{BaSO}_{4}$ adsorption does not significantly decrease its restorative activity (Figure 1, Table I). There appears to be remarkably little variation in the L.F. activity of plasma from different normal subjects (Table I). These observations confirm earlier reports $(8,11$, 21).

Non-oxalated normal serum tested 75 minutes after coagulation, has as much, and often more, restorative activity than the parent plasma tested simultaneously (Table II). On the other hand,

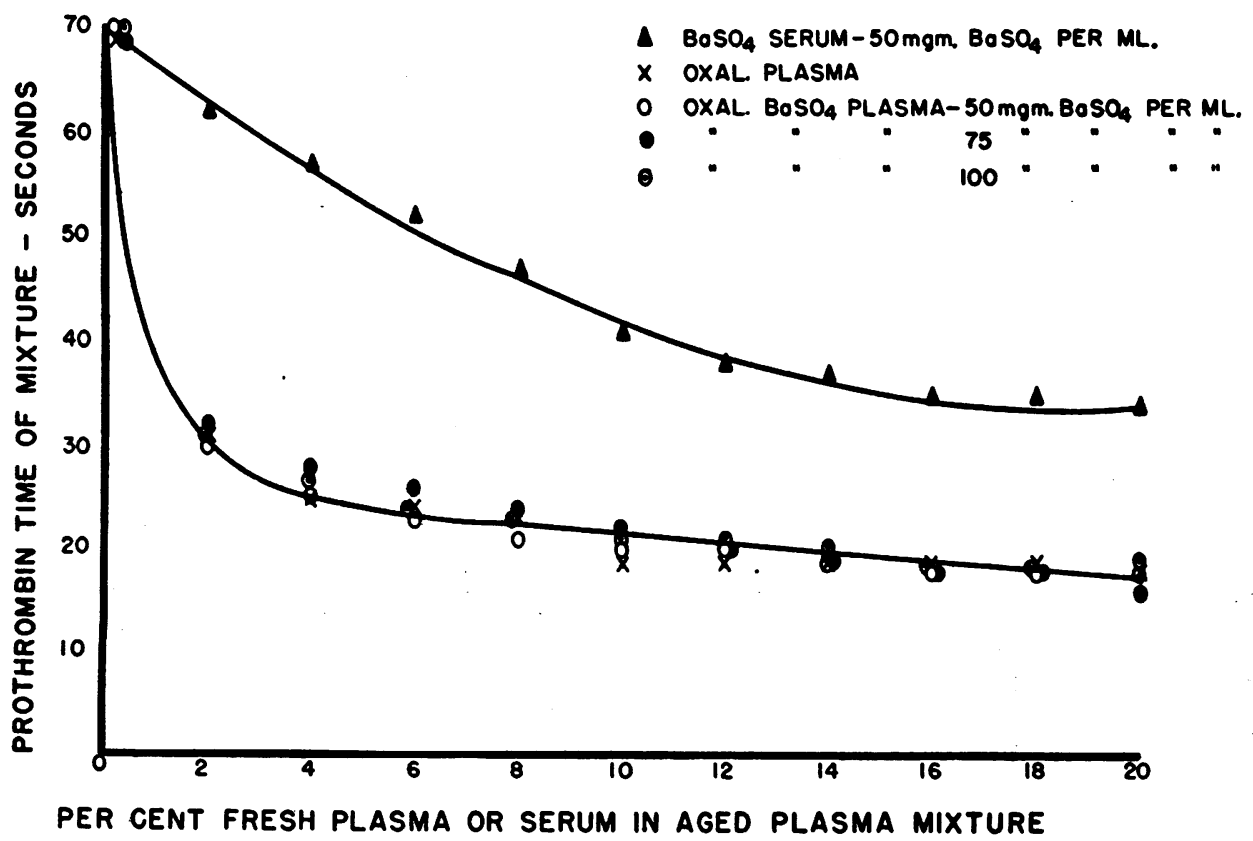

Fig. 1. Restorative Activity of Fresh Normal Plasma, BaSO, Normal Plasma, and Baso, Normal Serum on Retarded Prothrombin Conversion of Aged Plasua (Six WEERS AT $4^{\circ} \mathrm{C}$ ) 
TABLE I

Variation of L.F. in fresh normal oxalated plasma before and after adsorption with BaSO,

\begin{tabular}{|c|c|c|c|c|c|c|c|c|}
\hline \multirow{3}{*}{$\begin{array}{c}\text { Subject....... } \\
\begin{array}{c}\text { Per cent fresh } \\
\text { plasma in fresh } \\
\text { plasma-aged } \\
\text { plasma mixture }\end{array} \\
\end{array}$} & \multicolumn{8}{|c|}{ Prothrombin time (sec.) of plasma mixture } \\
\hline & \multicolumn{2}{|c|}{1} & \multicolumn{2}{|c|}{2} & \multicolumn{2}{|c|}{3} & \multicolumn{2}{|c|}{4} \\
\hline & $\begin{array}{l}\text { Whole } \\
\text { plasma }\end{array}$ & $\begin{array}{c}\mathrm{BaSO}_{\text {pasma }} \\
\text { plas }\end{array}$ & $\begin{array}{l}\text { Whole } \\
\text { plasma }\end{array}$ & $\begin{array}{l}\text { BaSO، } \\
\text { plasma }\end{array}$ & $\begin{array}{l}\text { Whole } \\
\text { plasma }\end{array}$ & $\begin{array}{c}\mathrm{BaSO}_{\text {pasma }} \\
\text { plase }\end{array}$ & $\begin{array}{l}\text { Whole } \\
\text { plasma }\end{array}$ & $\begin{array}{c}\text { BaSO، } \\
\text { plasma }\end{array}$ \\
\hline $\begin{array}{r}0 \\
1 \\
2 \\
4 \\
6 \\
10 \\
20\end{array}$ & $\begin{array}{l}87 \\
43 \\
36 \\
29 \\
27 \\
23 \\
19\end{array}$ & $\begin{array}{l}87 \\
46 \\
37 \\
29 \\
28 \\
26 \\
21\end{array}$ & $\begin{array}{l}87 \\
42 \\
35 \\
28 \\
24 \\
23 \\
20\end{array}$ & $\begin{array}{l}87 \\
46 \\
36 \\
30 \\
27 \\
24 \\
22\end{array}$ & $\begin{array}{l}87 \\
41 \\
34 \\
27 \\
25 \\
21 \\
20\end{array}$ & $\begin{array}{l}87 \\
42 \\
37 \\
30 \\
29 \\
25 \\
21\end{array}$ & $\begin{array}{l}87 \\
40 \\
35 \\
27 \\
26 \\
21 \\
19\end{array}$ & $\begin{array}{l}87 \\
44 \\
35 \\
30 \\
28 \\
24 \\
21\end{array}$ \\
\hline
\end{tabular}

$\mathrm{BaSO}_{4}$ serum is considerably less potent than the control serum (Table III). From interpolation of these data on the curve in Figure 1, it is evident that $\mathrm{BaSO}_{4}$ removes approximately 80 per cent or more of the restorative activity from serum whereas it does not do so from plasma.

Serum has certain clot-promoting properties not demonstrable in plasma (22). This is due to the serum prothrombin conversion accelerator (spca) which arises during coagulation and which in the presence of L.F. accelerates prothrombin conversion (22-24). Accordingly, the accelerating effect of serum on the prothrombin conversion in aged plasma might be due to both spca and L.F.

$\mathrm{BaSO}_{4}$ removes little, if any, L. F. from plasma $(8,21)$. It is assumed that it likewise does not remove this substance from serum. On the other hand, spca is quantitatively adsorbed $(22,24)$. Accordingly, $\mathrm{BaSO}_{4}$ serum is devoid of spca but should retain its full complement of L.F. That

\section{TABLE II}

Restorative activity of normal plasma and corresponding sera* on retarded prothrombin conversion of aged plasma

\begin{tabular}{rcc}
\multicolumn{3}{c}{ Proth-T $\begin{array}{c}\text { (sec.) of mixturet } \\
\text { Fresh } \\
\text { oxal. } \\
\text { plas. }\end{array}$} \\
Sal. & 18 & Ser. \\
113 & 18 & 19 \\
66 & 21 & 17 \\
33 & 17 & 17 \\
66 & 22 & 18 \\
37 & 18 & 16 \\
45 & & 16
\end{tabular}

* All sera separated one hour af ter clotting at room temperature in glass; both sera and plasma incubated at $37^{\circ} \mathrm{C}$ for additional 15 minutes and then tested.

$\uparrow$ Prothrombin time.

$\ddagger$ Mixture comprises $0.4 \mathrm{ml}$. of aged plasma plus $0.1 \mathrm{ml}$. of material indicated.
$\mathrm{BaSO}_{4}$ serum has less restorative ability than $\mathrm{BaSO}_{4}$ plasma indicates, therefore, that the L.F. of normal serum is far less than that of plasma.

\section{Effect of anti-coagulants upon restorative property of normal serum}

L.F. is more stable in citrated than in oxalated plasma $(8,25)$. It is also more stable in native plasma (containing calcium) but not in plasma rendered incoagulable by decalcifying with ionexchange resins (26). Experiments were performed in order to see whether the L.F. in serum is similarly affected (Table IV). The data indicate that the restorative property of oxalated serum is more labile than that of non-oxalated serum.

The question arises whether oxalate affects L.F., not adsorbable by $\mathrm{BaSO}_{4}$, or some other serum factor such as spca. Experiments performed on non-oxalated versus oxalated $\mathrm{BaSO}_{4}$ serum

TABLE III

Effect of $\mathrm{BaSO}_{4}$ adsorption on restorative activity of normal sera $(S)^{*}$ on prothrombin conversion of aged plasma (A.P.)

\begin{tabular}{c|c|c|c}
\hline \hline & \multicolumn{3}{|c}{ Proth-T (sec.) of mixture } \\
\cline { 2 - 3 } $\begin{array}{c}\text { Interval } \\
\text { between } \\
\text { clotting } \\
\text { and test }\end{array}$ & A.P. & $\begin{array}{c}\text { A.P. } \\
\text { plus } \\
\text { S }\end{array}$ & $\begin{array}{c}\text { A.P. } \\
\text { plus } \\
\text { BaSOs St }\end{array}$ \\
\cline { 2 - 4 } & & & \\
hrs. & & 19 & 31 \\
$3 \frac{1}{2}$ & 33 & 21 & 31 \\
2 & 45 & 21 & 34 \\
$3 \frac{1}{2}$ & 37 & 21 & 32 \\
2 & 48 & 22 & 42 \\
$1 \frac{1}{2}$ & 66 & & \\
\hline
\end{tabular}

* Non-oxalated sera, separated one hour after blood was shed. One part serum added to four parts A.P.

† Sera adsorbed with $50 \mathrm{mgm}$. BaSO, per $\mathrm{ml}$. 
TABLE IV

Deterioration of serum L.F. in presence of oxalate* and citrate*

Prothrombin time (sec.)

\begin{tabular}{l|c|c|c|c|c|c}
\hline \hline & \multicolumn{3}{|c|}{$\begin{array}{c}75 \text { min. } \\
\text { after coag. }\end{array}$} & \multicolumn{3}{|c}{$\begin{array}{c}195 \text { min. } \\
\text { after coag. }\end{array}$} \\
\cline { 2 - 8 } & I & II & III & I & II & III \\
\hline Aged plas. & 37 & 37 & 37 & 37 & 37 & 37 \\
Aged plas. plus: $t$ & 16 & 15 & 14 & 21 & 17 & 18 \\
Ser. & 17 & 18 & 18 & 21 & 24 & 22 \\
Cit. ser. & 18 & 19 & 19 & 28 & 40 & 38 \\
Oxal. ser. & & & & & &
\end{tabular}

* Oxalate and citrate added to normal serum $60 \mathrm{~min}$. after coagulation.

$\dagger 0.1 \mathrm{ml}$. serum added to $0.4 \mathrm{ml}$. of aged plasma.

(Table V) indicate that the latter, also, was more labile than its non-oxalated counterpart. On the basis of the assumption that $\mathrm{BaSO}_{4}$ does not remove L.F. from serum, it is concluded that oxalate accelerates deterioration of this clotting component.

The restorative activity seems more stable in citrate than in oxalate but not as stable as in native serum (Table IV). It appears, therefore, that L.F. deteriorates more rapidly in serum containing oxalate than in native or citrated serum. The same is observed in plasma $(8,17,25,26)$.
TABLE V

Effect of oxalate on L.F. activity of normal serum $(S)$

$\begin{array}{lc}\begin{array}{c}\text { Aged plasma } \\ \text { plus: }\end{array} & \begin{array}{c}\text { Proth-T } \\ \text { (sec.) }\end{array} \\ \text { Saline } & 61 \\ \text { Fresh S } & 17 \\ \text { Fresh BaSO, S } & 31 \\ \text { Fresh oxal. S } & 19 \\ \text { Fresh oxal. BaSO, S } & 38 \\ \text { S kept } 3 \text { hrs., room temp. } & 20 \\ \text { BaSO, S kept 3 hrs., room temp. } & 42 \\ \text { Oxal. S kept 3 hrs., room temp. } & 32 \\ \text { Oxal. BaSO, S kept 3 hrs., room temp. } & 55\end{array}$

Sera separated one hour after clotting.

$\mathrm{BaSO}_{4}$ sera prepared with $100 \mathrm{mgm}$. BaSO, per $\mathrm{ml}$.

* One part material added to four aged plasma (60 days at $4-5^{\circ} \mathrm{C}$.

\section{Consumption of L.F. and prothrombin during nor- mal coagulation}

That L.F. disappears from blood during coagulation is clearly established. Its rate of disappearance was studied in relation to the rate of prothrombin consumption. Aliquots of freshly drawn blood were allowed to clot at $37^{\circ} \mathrm{C}$ in separate dry test tubes. At specified intervals oxalate was added, the mixture was stirred with a glass rod and immediately centrifuged at 2000 r.p.m. for 10 minutes. The sera were separated and subjected to determination of residual prothrombic activity

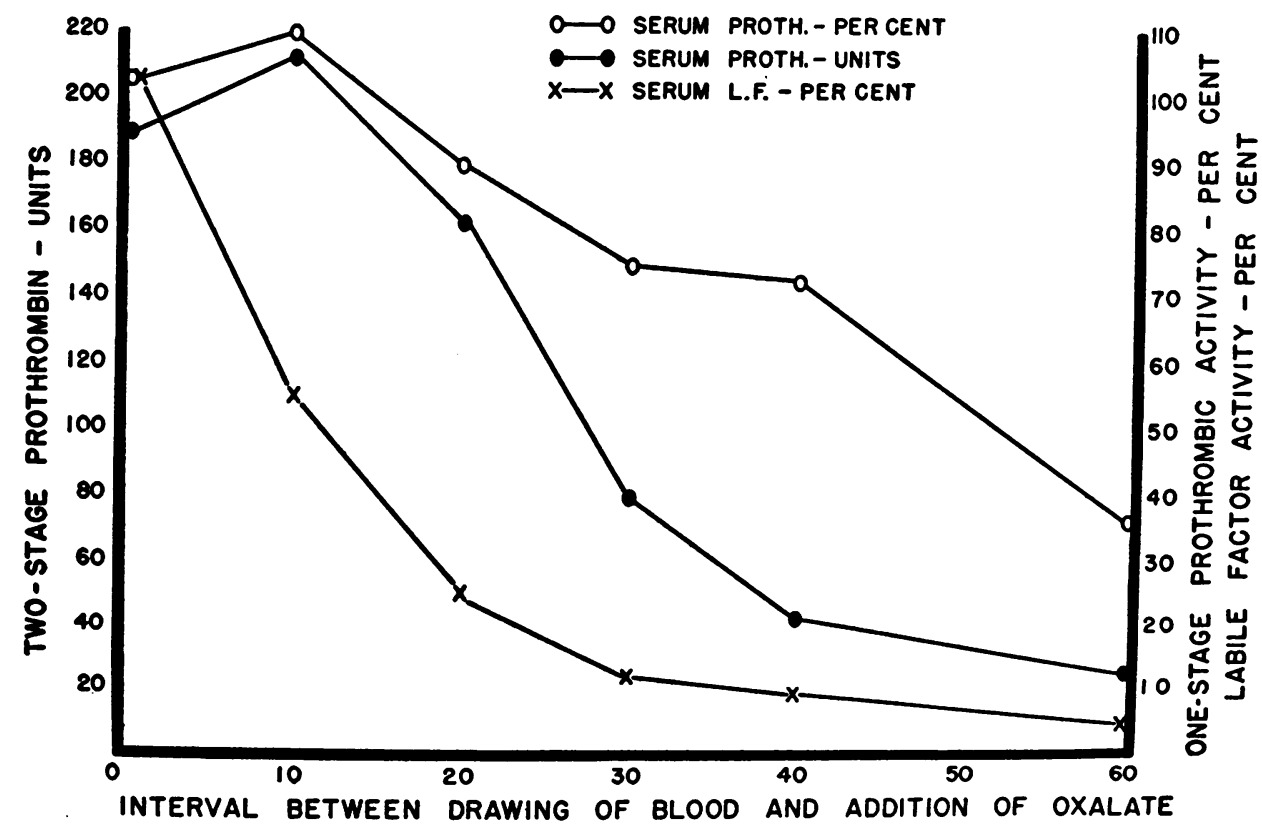

Fig. 2. Labile Factor, and One-Stage and Two-Stage Prothrombic Activities of "Serum" during Coagulation of Normal Blood

Aged plasma on which L. F. activities were tested had a prothrombin time of $65 \mathrm{sec}$. 


\section{TABLE VI}

Effect of thromboplastin (TPL) supplement to clotting blood on L.F. in normal serum $(S)$ (non-oxalated)

$\begin{gathered}\text { Aged plasma } \\ \text { plus: }\end{gathered}$
Saline
$\mathrm{S}_{\mathrm{BaSO}_{4} \mathrm{~S}}$
$\mathrm{TPL} \mathrm{S}_{\mathrm{TPL}} \mathrm{BaSO}_{4} \mathrm{~S}$

\begin{tabular}{cc}
\multicolumn{2}{c}{ Proth-T (sec.) } \\
Exp't 1* & Exp't 2† \\
47 & 63 \\
25 & 33 \\
30 & 44 \\
34 & 47 \\
39 & 64
\end{tabular}

$\mathrm{BaSO}_{4} \mathrm{~S}$ prepared with $25 \mathrm{mgm}$. BaSO, per $\mathrm{ml}$. TPL S obtained from blood (nine vol.) added to TPL solution (one vol.) prepared as for prothrombin determination. Identical results were obtained when the ratio was 19 to 1 .

* One volume of material to four of aged plasma.

† One volume of material to one of aged plasma.

by both one- and two-stage methods. Aliquots of the serum were also adsorbed with $\mathrm{BaSO}_{4}$ (50 mgm. per ml.) and were then tested for L.F. activity. It is evident (Figure 2 ) that both L.F. and prothrombin disappear during the coagulation process. Whereas L.F. began to decrease promptly after the blood was shed, the two-stage prothrombin values showed no significant change within the first 10 minutes. Within 40 minutes most of both clotting factors had disappeared.
There was considerable discrepancy between the one- and two-stage prothrombin values. This is not surprising since one-stage prothrombin times of serum reflect the concentration not only of unconsumed prothrombin but also of residual L.F. together with evolved spca.

It is of interest that within the first 10 minutes, about one-half of the L.F. had disappeared, before any detectable (by the methods used) decrease in prothrombin. Although this must be significant in the role of L.F. in prothrombin conversion, the evidence is too meager to permit any interpretation.

Effect of thromboplastin on concentration of L.F. in serum

Since thromboplastin added to normal blood yields serum which is always devoid of prothrombin in contrast to normal sera which often show small amounts, it was of interest to study the L.F. content of such sera. Sera from thromboplastinsupplemented blood were far less able to restore prothrombic activity to aged plasma than sera from spontaneously clotted blood (Table VI). This

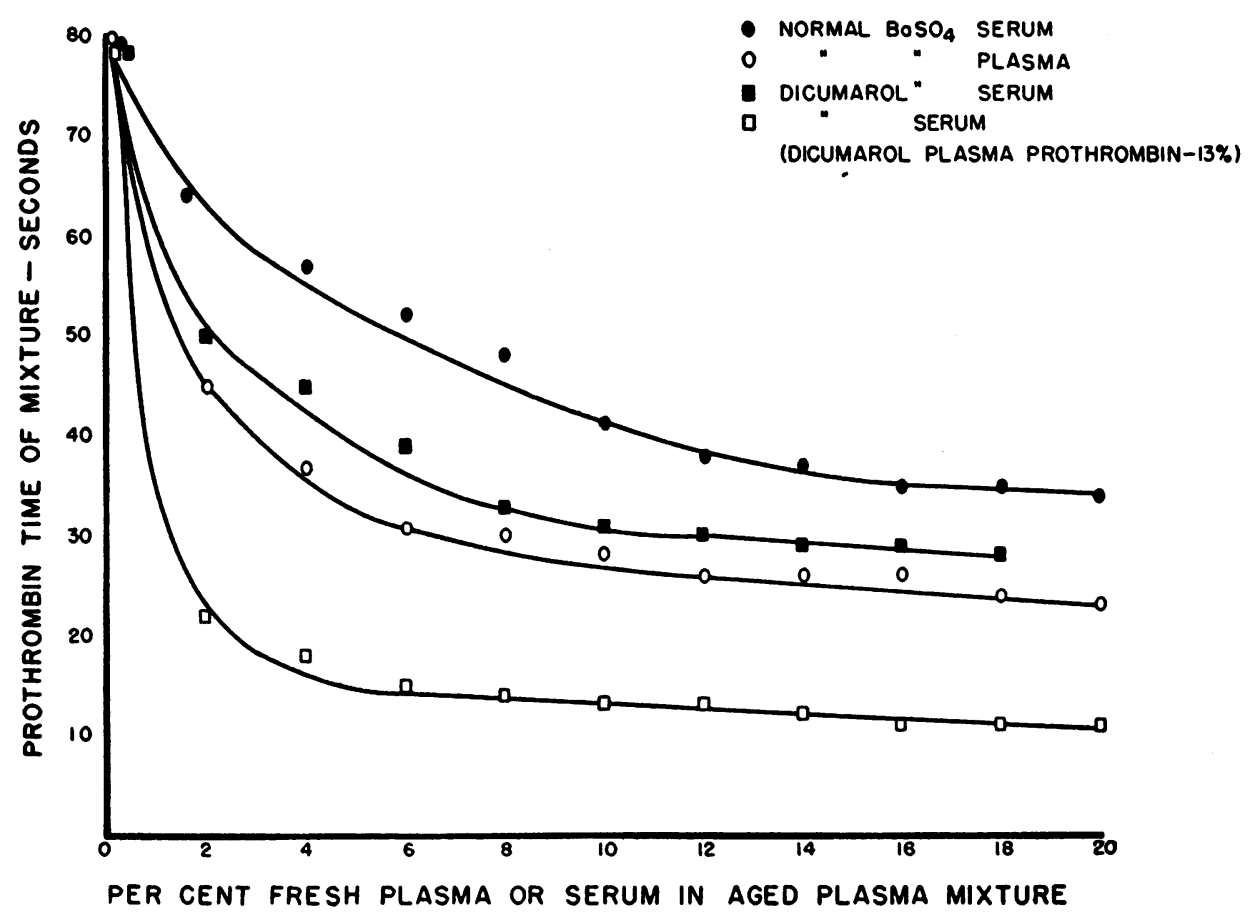

Fig. 3. Restorative Activity of "Dicumarol" Serum on Retarded Prothrombin Conversion of Aged Normal Plasma

Serum was non-oxalated, and was tested 11/2 hours after the blood was obtained. Adsorption with $\mathrm{BaSO}_{4}$ was carried out with $50 \mathrm{mgm}$. per $\mathrm{ml}$. 
difference, evident also in the $\mathrm{BaSO}_{4}$ adsorbed sera, suggests that more L.F. is consumed when coagulation and prothrombin conversion are accelerated by thromboplastin.

\section{L.F. in serum from dicumarolized blood ${ }^{\mathrm{S}}$}

The purpose of these experiments was to study L.F. depletion during coagulation in relation to the amount of prothrombin available for conversion to thrombin. Dicumarolized blood contains essentially normal amounts of L.F. (17). As is evident in Figure 3, dicumarol serum has a very strong restorative effect on aged plasma, more potent than normal serum (compare with data of Table II; also compare data in Table VII with those in Table $\mathrm{V}$, all obtained on the same aged plasma). The same is true of dicumarol $\mathrm{BaSO}_{4}$

\begin{tabular}{cc}
\multicolumn{2}{c}{ TABLE vII } \\
L.F. activity of dicumarol serum (D.S.) \\
with and without oxalate \\
$\begin{array}{c}\text { Aged plasma* } \\
\text { plus: }\end{array}$ & $\begin{array}{c}\text { Proth-T } \\
\text { (sec.) }\end{array}$ \\
Saline & 61 \\
Fresh D.S. & 11 \\
Fresh oxal. D.S. & 14 \\
Fresh BaSO, D.S. & 26 \\
Fresh BaSO, D.S.-oxal. & 39 \\
D.S. kept 3 hrs., room temp. & 13 \\
Oxal. D.S., 3 hrs., room temp. & 22 \\
BaSO, D.S., 3 hrs., room temp. & 36 \\
BaSO, oxal. D.S., 3 hrs., room temp. & 64
\end{tabular}

The prothrombic activity of the parent plasma was 11 per cent. Serum separated one hour after clotting. $\mathrm{BaSO}_{4} \mathrm{~S}$ prepared with $100 \mathrm{mgm}$. BaSO, per $\mathrm{ml}$.

* One volume of material to four of aged plasma ( 60 days at $4-5^{\circ} \mathrm{C}$ ).

serum compared with its normal counterpart. Again, as with normal serum, oxalate accelerated L.F. deterioration (Table VII).

It was of interest to study the stability of L.F. in dicumarol serum as contrasted with normal serum. Accordingly, experiments were performed on the same sera recorded in Tables V and VII, after three days' storage at $4-5^{\circ} \mathrm{C}$. Determinations were made with the same stored plasma which now had a prothrombin time of 80 seconds compared with 61 seconds three days earlier. The three-day-old normal serum lowered the prothrombin time from 80 to 64 seconds, whereas the three-day-old dicumarol serum reduced it to 32 .

5 Obtained from patients with myocardial infarct treated with dicumarol for the prevention of thromboembolic disease.
Whether this difference, however, reflected a greater lability, or a lesser initial concentration, of L.F. in the normal serum is not clear.

The oxalated dicumarol serum became inert within three days.

\section{Effect of thromboplastin on L.F. of dicumarol serum}

As already shown, thromboplastin added to normal blood reduced serum L.F. activity. On dicumarol blood this effect was not observed. Serum derived from thromboplastin supplemented dicumarol blood contained the same L.F. activity as dicumarol serum derived without the thromboplastin. This was true whether non-oxalated was compared with oxalated serum, and $\mathrm{BaSO}_{4}$ compared with non- $\mathrm{BaSO}_{4}$ serum under the same conditions. It appears, therefore, that the effect of thromboplastin on the L.F. concentration of normal serum was related to the velocity and/or the amount of prothrombin conversion.

Again, in dicumarol-thromboplastin serum L.F. was much less stable in the presence of oxalate.

In these experiments $0.3 \mathrm{ml}$. of thromboplastin extract was added to $10 \mathrm{ml}$. of dicumarol blood containing 3 per cent prothrombin. The aged plasma on which the sera were tested had a prothrombin time of 37 seconds.

\section{L.F. in hemophilic serum}

Hemophilic serum has more restorative activity on aged plasma than normal serum (Table VIII), despite the fact that the interval between the shedding of the blood and the testing of the serum was

TABLE VIII

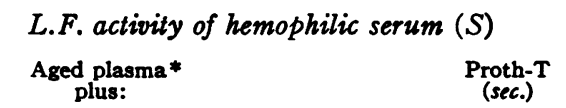

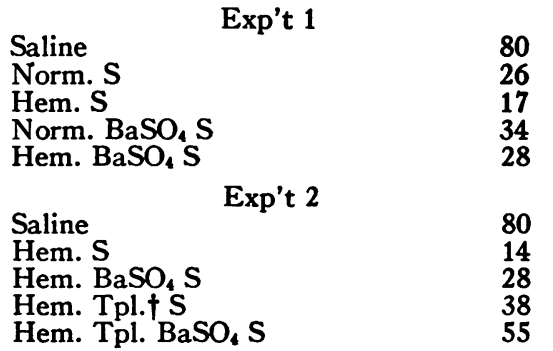

* One volume of material added to four of aged plasma. Sera non-oxalated, separated one hour after clotting. $\mathrm{BaSO}_{4} \mathrm{~S}$ obtained with $50 \mathrm{mgm}$. BaSO, per $\mathrm{ml}$.

$\dagger$ One volume of thromboplastin extract to nine of blood. 
inevitably greater as a result of the prolonged clotting time of the hemophilic blood. Also, $\mathrm{BaSO}_{4}$ removes some restorative activity.

As in all the other experiments, oxalated serum from hemophilic blood had far less restorative ability than non-oxalated sera. This was true with whole as well as $\mathrm{BaSO}_{4}$-adsorbed serum.

Supplementing hemophilic blood with thromboplastin, which accelerates coagulation, yields serum containing far less L.F. activity, practically the same as that observed in serum from normal blood similarly supplemented (Table VIII).

\section{Serum L.F. in thrombocytopenia and throm- basthenia}

These findings led to experiments in other pathological conditions where prothrombin conversion is reduced as a consequence of inadequate elaboration of thromboplastic material. It is evident (Table IX) that in thrombocytopenic purpura as well as in thrombasthenia, two disorders where prothrombin consumption is poor $(15,27)$, serum L.F. activity was abnormally elevated. In these cases, the $\mathrm{BaSO}_{4}$ sera also were more potent in rectifying the retarded prothrombin conversion of aged plasma than $\mathrm{BaSO}_{4}$ normal serum. In all instances, the $\mathrm{BaSO}_{4}$ removed the large amounts of residual prothrombic activity characteristically

TABLE IX

\section{Serum (S) L.F. in thrombocytopenic purpura and thrombasthenia}

Pat. 1-W. Idiopathic thrombocytopenic purpura.

Pat. 2-E. Acute idiopathic thrombocytopenic purpura; quinidine sensitivity.

Pat. 3-G. Easy bruising, ecchymoses, normal to increased bleeding time, increased capillary fragility for years. High residual serum prothrombic activity. Platelet count: 122,000 per mm. blood (low normal).

\begin{tabular}{|c|c|c|c|c|}
\hline \multicolumn{5}{|c|}{ Prothrombin time (sec.) of mixture } \\
\hline \multirow{2}{*}{$\begin{array}{l}\text { Aged plasma* } \\
\text { plus: }\end{array}$} & \multicolumn{3}{|c|}{ Thrombocytopenia } & \multirow{2}{*}{$\begin{array}{c}\text { Thrombas } \\
\text { thenia }\end{array}$} \\
\hline & Pat. 1 & & t. 2 & \\
\hline $\begin{array}{l}\text { Saline } \\
\text { Norm. Plas. } \\
\text { Pat. Plas. } \\
\text { Norm. S } \\
\text { Pat. S } \\
\text { Norm. BaSO }, ~ \\
\text { Pat. BaSO } 4\end{array}$ & \begin{tabular}{|c|}
36.000 plts. \\
66 \\
16 \\
16 \\
31 \\
16 \\
37 \\
23
\end{tabular} & \begin{tabular}{|c|}
18,000 plts. \\
67 \\
19 \\
21 \\
15 \\
13 \\
37 \\
26
\end{tabular} & $\begin{array}{c}130,000 \text { plts. } \\
68 \\
20 \\
20 \\
\\
37 \\
33\end{array}$ & $\begin{array}{l}76 \\
\\
21 \\
18 \\
61 \\
50\end{array}$ \\
\hline
\end{tabular}

* One volume of material to four volumes of aged plasma. $\dagger$ After clinical recovery. present in serum in these disorders. Recovery in one patient with acute thrombocytopenia was associated with restoration of serum L.F. and prothrombin to normal values.

\section{L.F. in "serum" from afibrinogenemic subject}

Experiments performed on blood from a subject with afibrinogenemia ${ }^{6}$ exclude the possibility that L.F. disappears during coagulation as a result of adsorption on the fibrin clot. Blood was drawn with and without added oxalate; the latter remained completely fluid indefinitely. One hour after the blood was shed, oxalate was added to the non-oxalated sample. The bloods were centrifuged. The plasma and "serum" were then incubated at $37^{\circ} \mathrm{C}$ for 15 minutes. Plasma prothrombin was normal by both one- and two-stage methods. The L.F. activity of the plasma also was normal. The "serum" contained no prothrombin by the two-stage procedure, and the L.F. activity of the $\mathrm{BaSO}_{4}$ adsorbed "serum" was approximately 10 per cent of that of the parent plasma. Also of interest was the finding that the unadsorbed serum contained a normal amount of spca. These observations indicate that the disappearance of L.F. activity during coagulation is not related to formation of a fibrin clot. It may be concluded, furthermore, that spca elaboration is also independent of fibrinogen and its conversion to fibrin.

\section{DISCUSSION}

Although the importance of a non-prothrombin plasma constituent in the conversion of prothrombin by thromboplastin plus calcium is now definitely established, its role in this reaction is obscure. Quick and his collaborators, who have designated the entity by the term "Labile Factor" because of its lability, claim that it enters into the reaction stoichiometrically along with thromboplastin and calcium (28). On the other hand, the Wayne University group (Ware, Seegers, and colleagues), calling their substance "plasma Acglobulin," consider it to be a relatively inert precursor of "serum Ac-globulin" to which it becomes converted by thrombin. Serum Ac-globulin then functions as an accelerator of the activation of

6 We are indebted to Dr. Louis $\mathrm{K}$. Diamond of the Children's Medical Center, Boston, for making blood, from this patient, available. 
prothrombin $(4,29,30)$. Owren, who holds similar views, terms his substance Factor $V$ which is converted to Factor VI during coagulation, and which accelerates thrombin elaboration $(12,5)$.

Regardless of whether these moieties are identical (and it is becoming increasingly evident that they are), certain facts are clear. When L.F. is progressively reduced below 50 per cent of that in normal plasma, the prothrombin time increases (8). Prothrombin consumption is also curtailed (31). Thus, a given prothrombin time reflects the amount of L.F. (or plasma Ac-globulin and Factor V, if we assume that they are identical) as well as the concentration of prothrombin itself. Accordingly, in order to measure prothrombin as such, adequate quantities of this other factor must be assured. This point has received scant consideration in reports on serum prothrombin and on prothrombin consumption during coagulation, especially those based upon one-stage prothrombin determinations, where the velocity of prothrombin conversion is measured.

The foregoing data, in accordance with recent reports $(28,32)$, show that substantial amounts of L.F. disappear during normal coagulation. Depletion of L.F. begins before prothrombin falls off, but soon the rates with which both are consumed seem parallel. Accelerating and increasing prothrombin conversion with supplements of thromboplastin causes greater losses. Conversely, in hemophilia, thrombocytopenia, and thrombasthenia where prothrombin conversion is retarded or reduced, L.F. consumption appears reduced. Furthermore, curtailing the amount of available prothrombin also decreases the amount of L.F. consumed.

Accelerating coagulation and increasing prothrombin consumption in hemophilia by additions of thromboplastin induces greater L.F. consumption. It may, therefore, be concluded that this clotting factor is utilized in relation to the amount and/or velocity of prothrombin consumption. Furthermore, critically curtailing the concentration of L.F. limits the velocity as well as the amount of thrombin evolution (33). These findings lend support to the idea that L.F. enters into the reaction as a real participant rather than the alternative view that it is merely an "accelerator" acting outside the thrombin-forming system proper. This is in accordance with the interpretation of
Quick and Stefanini (28) regarding L.F. and Lewis and Ferguson concerning Ac-globulin (34).

The amount of L.F. in serum is considerably influenced by the presence of decalcifying anticoagulants and the interval of time elapsing after coagulation. These facts must be considered in studies where these agents may be added to blood at various intervals after blood is shed in order to stop prothrombin conversion at various stages of the coagulation process. It is noteworthy that L.F. deteriorates more rapidly in oxalated than in citrated serum, as in plasma under the same condition.

All of these facts are pertinent to the determination of serum prothrombin and prothrombin consumption by the one-stage method. The orthodox procedure (18), modified by the addition of fibrinogen, will give grossly inaccurate results for two reasons: (a) During coagulation the L.F. disappears to a variable extent, which is considerably influenced by conditions of coagulation. Consumption of L.F. may reduce its concentration in serum to critically low levels, thus causing elevated prothrombin times. (b) Also, the prothrombin conversion accelerator (spca) which evolves during coagulation varies in its concentration in serum, again depending upon various conditions of coagulation (23). This clot-promoting factor increases the velocity of prothrombin conversion by thromboplastin and calcium, resulting in shorter prothrombin times than can be attributed to the prothrombin itself. It has already been shown that for this reason, one-stage determinations of the prothrombin in serum are inaccurate (15). Now there is additional basis for this conclusion.

Difficulties also arise in the determination of serum L.F. by the one-stage procedure. Clearly, the substance is measurable by its restorative activity on aged plasma in which this clotting factor has largely deteriorated. Thus, the restorative effect of serum might validly be considered a measure of L.F. if we could be sure that during coagulation alterations did not take place in components other than prothrombin or L.F., which might influence the velocity of prothrombin conversion in aged plasma. That such alterations do occur, however, has been shown conclusively. Spca evolves which, in the presence of L.F., will accelerate thrombin evolution in stored plasma (24). Seegers and his group had shown earlier that serum and serum 
fractions activate and accelerate prothrombin conversion to a greater degree than plasma, and Owren has reported similar observations (12). Also, Milstone found that in the course of coagulation, "prothrombokinase" is converted to "thrombokinase" which is a potent accelerator of prothrombin conversion (35).

It is accordingly evident that some consideration must be given to clot-promoting agents which arise as a consequence of the coagulation process, and which may accelerate prothrombin conversion in aged plasma, simulating or enhancing L.F. activity. This is substantiated by the observations that $\mathrm{BaSO}_{4}$ removes considerable restorative activity from serum despite the fact that this agent does not appreciably adsorb L.F. Since $\mathrm{BaSO}_{4}$ removes spca (23) and thrombokinase (35), the effect on the restorative activity of serum is attributed to removal of this (these) substance(s). It should also be noted that $\mathrm{BaSO}_{4}$ also adsorbs residual serum prothrombin. The restorative activity of $\mathrm{BaSO}_{4}$ treated serum is, therefore, a more accurate index of serum L.F. than untreated serum.

The question arises whether serum Ac-globulin and Factor VI can be similarly excluded. According to Murphy and Seegers (36) and as has been confirmed by us (24), serum Ac-globulin is extremely unstable in normal human serum, virtually disappearing shortly after coagulation. The same is said to be true of Factor VI (12). This does not necessarily obviate the need for considering these factors because under abnormal conditions of coagulation they may be more stable, persisting in the serum. Indeed, substantial Ac-globulin activity is demonstrable in human serum prepared from blood allowed to clot slowly in siliconized tubes (36).

In a previous paper (24) evidence was presented which indicated that "serum" Ac-globulin probably comprises a mixture of plasma Ac-globulin (L.F.) plus spca, which together account for its greater prothrombin-converting activity than plasma Ac-globulin alone. The relatively low initial concentration of Ac-globulin in human plasma and its rapid depletion during coagulation explains the apparent extreme lability of "serum" Ac-globulin in human, in contrast to bovine, serum. On the basis of this interpretation, and assuming Factor VI to be identical with "serum" Ac-globulin, removal of spca by adsorption with $\mathrm{BaSO}_{4}$ adequately takes care of clot-promoting activity of serum over and above that of its parent plasma as far as the restorative effect of serum on aged plasma is concerned.

In evaluating the restorative effect of serum as a measure of its L.F. content, consideration should also be given to the products of platelet disintegration which are said to accelerate prothrombin conversion in aged plasma $(37,38)$. It appears that platelets contain at least two clot-promoting substances, one which resembles Ac-globulin, and another which accelerates the interaction of thrombin with fibrinogen $(39,30) .^{7}$ Whether these appear, and persist, in serum as a consequence of clotting is not clear. Pending further investigation, it may be concluded that the restorative effect of $\mathrm{BaSO}_{4}$ serum on aged plasma provides a suitable method for measuring serum L.F. By comparing the prothrombin times of mixtures containing various dilutions of $\mathrm{BaSO}_{4}$ serum in aged plasma with similar mixtures containing the $\mathrm{BaSO}_{4}$ parent plasma, the L.F. of the serum in per cent of that originally present in the blood can be determined.

\section{CONCLUSIONS}

1. Normal serum has as much, and frequently more, restorative activity than the parent plasma on the retarded prothrombin conversion of aged plasma.

2. This is largely due to spca which evolves during coagulation and which, together with whatever Labile Factor remains unconsumed, accelerates prothrombin conversion.

3. Removal of spca by adsorption with $\mathrm{BaSO}_{4}$ yields a serum which still has some restorative activity. This activity is a measure of residual L.F. in serum, which under normal conditions is small.

4. L.F. begins to disappear from blood shortly after its withdrawal, even before detectable changes in the prothrombin concentration have occurred. Within 40 minutes consumption of both factors is virtually complete. Disappearance of L.F. during coagulation is unrelated to the conversion of fibrinogen to fibrin.

\footnotetext{
It has previously been shown that spca does not act on this phase of the coagulation process $(22,24)$.
} 
5. Accelerating coagulation and prothrombin conversion by thromboplastin supplements increases the amount of L.F. consumed.

6. Conversely, curtailing the amount of prothrombin converted to thrombin, by dicumarol or by pathological conditions such as hemophilia, thrombocytopenia or thrombasthenia results in sera containing abnormally large amounts of L.F. This could be corrected in hemophilia by thromboplastin supplements, but not in dicumarol blood.

7. These observations lend support to the concept that L.F. is an active participant in the prothrombin conversion reaction.

8. Serum L.F. seems more stable in citrate than in oxalate, but not as stable as in native serum. This is in accordance with its behavior in plasma under similar conditions.

9. These findings are discussed insofar as they relate to methods for the determination of serum prothrombin, serum L.F. and prothrombin consumption under normal and pathological conditions.

\section{REFERENCES}

1. Alexander, B., Landwehr, G., and Goldstein, R., Labile factor of prothrombin conversion: its consumption in normal and abnormal blood coagulation. Federation Proc., 1950, 9, 4.

2. Quick, A. J., On the constitution of prothrombin. Am. J. Physiol., 1943, 140, 212.

3. Quick, A. J., Components of the prothrombin complex. Am. J. Physiol., 1947, 151, 63.

4. Ware, A. G., Guest, M. M., and Seegers, W. H., A factor in plasma which accelerates the activation of prothrombin. J. Biol. Chem., 1947, 169, 231.

5. Owren, P. A., The fifth coagulation factor (Factor V). Preparation and properties. Biochem. J., 1948, 43, 136.

6. Fantl, P., and Nance, M. H., Acceleration of thrombin formation by a plasma component. Nature, 1946, 158, 708.

7. Fantl, P., and Nance, M. H., The physiological activation of prothrombin. M. J. Australia, 1948, 1, 128.

8. Alexander, B., and de Vries, A., Human prothrombin: quantitative studies on the plasma labile factor, and the restorative effects of normal, hypofibrinogenemic and hemophilic plasma on the prothrombin of stored plasma. J. Clin. Invest., 1949, 28, 24.

9. Loomis, E. C., and Seegers, W. H., Is prothrombin a unitary principle or a complex? Am. J. Physiol., 1947, 148, 563.

10. Fahey, J. L., Ware, A. G., and Seegers, W. H., Stability of prothrombin and Ac-globulin in stored human plasma as influenced by conditions of storage. Am. J. Physiol., 1948, 154, 122.
11. Honorato, R., and Quick, A. J., The relation of fibrinogen to the coagulation factor which diminished in stored plasma. Am. J. Physiol., 1947, 150, 405.

12. Owren, P. A., The coagulation of blood: investigations on a new clotting factor. Acta med. Scandinav., 1947, Suppl. 194.

13. Owren, P. A., Parahaemophilia: hemorrhagic diathesis due to the absence of previously unknown clotting factor. Lancet, 1947, 1, 446.

14. Frank, R., Bilhan, N., and Ekren, H., Die Parahämophilie (Owren), Eine Neue Form der Hämorrhagischen Diathese. Acta haemat., 1950, 3, 70.

15. Alexander, B., and Landwehr, G., Prothrombin consumption, serum prothrombic activity and prothrombin conversion accelerator in hemophilia and thrombocytopenia. J. Clin. Invest., 1949, 28, 1511 ; Federation Proc., 1949, 8, 2.

16. Quick, A. J., and Favre-Gilly, J. E., The prothrombin consumption test: its clinical and theoretic implications. Blood, 1949, 4, 1281.

17. Quick, A. J., and Stefanini, M., The concentration of the labile factor of the prothrombin complex in human, dog and rabbit blood; its significance in the determination of prothrombin activity. J. Lab. \& Clin. Med., 1948, 33, 819.

18. Quick, A. J., The clinical application of the hippuric acid and the prothrombin tests. Am. J. Clin. Path., 1940, 10, 222.

19. Rosenfield, R. E., and Tuft, H. S., Estimation of prothrombin level from prothrombin time. Am. J. Clin. Path., 1947, 17, 405.

20. Ware, A. G., and Seegers, W. H., Two-stage procedure for the quantitative determination of prothrombin concentration. Am. J. Clin. Path., 1949, 19, 471.

21. Stefanini, M., and Quick, A. J., The effect of various adsorbants on the components of the prothrombin complex. Federation Proc., 1949, 8, 255.

22. de Vries, A., Alexander, B., and Goldstein, R., A factor in serum which accelerates the conversion of prothrombin to thrombin. I. Its determination and some physiologic and biochemical properties. Blood, 1949, 4, 247.

23. Alexander, B., de Vries, A., and Goldstein, R., A factor in serum which accelerates the conversion of prothrombin to thrombin. II. Its evolution with special reference to the influence of conditions which affect blood coagulation. Blood, 1949, 4, 739.

24. Alexander, B., Goldstein, R., and Landwehr, G., The prothrombin conversion accelerator of serum (SPCA): its partial purification and properties compared with serum Ac-globulin. J. Clin. Invest., $1950,29,881$.

25. Quick, A. J., The components of prothrombin. Proc. Soc. Exper. Biol. \& Med., 1946, 62, 249.

26. Quick, A. J., and Stefanini, M., The chemical state of the calcium reacting in the coagulation of blood. J. Gen. Physiol., 1948, 32, 191. 
27. Alexander, B., and Landwehr, G., Thrombasthenia and thrombocytopenia purpura. New England J. Med., 1949, 241, 965.

28. Quick, A. J., and Stefanini, M., Nature of action of labile factor in formation of thrombin. Am. J. Physiol., 1950, 160, 572.

29. Ware, A. G., and Seegers, W. H., Plasma accelerator globulin: partial purification, quantitative determination and properties. J. Biol. Chem., 1948, 172, 699.

30. McClaughry, R. I., and Seegers, W. H., Prothrombin, thromboplastin, Ac-globulin and platelet accelerator: quantitative interrelationships. Blood, 1950, 5, 303 .

31. Quick, A. J., and Stefanini, M., The state of component A (prothrombin) in human blood; evidence that it is partly free and partly in an inactive or precursor form. J. Lab. \& Clin. Med., 1949, 34, 1203.

32. Honorato, R., Rojas, C., and Ivanovic, N., Destruccion del Cofactor Plasmatico de la Tromboplastina. Consumo de Este Factor en la Coagulation Sanguinea. Bol. Soc. biol. Santiago de Chile, 1949, 7, 35 .

33. Quick, A. J., and Stefanini, M., The concentration of component $\mathrm{A}$ in blood; its assay and relation to the labile factor. J. Lab. \& Clin. Med., 1949, 34, 973.
34. Lewis, J. H., and Ferguson, J. H., Thrombin formation. I. The role of calcium, serum Ac-globulin and tissue thromboplastin. J. Clin. Invest., 1948, 27, 778.

35. Milstone, J. H., Three-stage analysis of blood coagulation. J. Gen. Physiol., 1948, 31, 301.

36. Murphy, R. C., and Seegers, W. H., Concentration of prothrombin and Ac-globulin in various species. Am. J. Physiol., 1948, 154, 134.

37. Mann, F. D., Hurn, M., and Magath, T. B., Observations on the conversion of prothrombin to thrombin. Proc. Soc. Exper. Biol. \& Med., 1947, 66, 33.

38 Mann, F. D., Hurn, M., and Mathieson, D. R., Platelets as foci in the coagulation of blood. Am. J. Physiol., 1949, 158, 84.

39. Ware, A. G., Fahey, J. L., and Seegers, W. H., Platelet extracts, fibrin formation and interaction of purified prothrombin and thromboplastin. Am. J. Physiol., 1948, 154, 140.

40. Seegers, W. H., and Ware, A. G., Protein equilibrium reactions in the blood clotting mechanism. First Conf. on Blood Clotting and Allied Problems, Josiah Macy, Jr. Foundation, 1948, p. 75.

41. Flynn, J. E., and Standley, E. T., On the conversion of prothrombin to thrombin. Second Conf. on Blood Clotting and Allied Problems, Josiah Macy, Jr. Foundation, 1949, p. 145.

\section{ASSOCIATION ANNOUNCEMENT}

The 43rd annual meeting of the American Society for Clinical Investigation will be held at the Chalfonte-Haddon Hall, Atlantic City, N. J., on Monday, April 30, 1951, at 9 a.m.

Other meetings to be held also at the Chalfonte-Haddon Hall are:

The 8th annual meeting of the American Psychosomatic Society, Satuday, April 28, 1951.

The National Meeting of the American Federation for Clinical Research, Tuesday, May 1, 1951.

The 64th meeting of the Association of American Physicians, Tuesday, May 1, and Wednesday, May 2, 1951. 